\section{Paclobutrazol or Ancymidol Effects on Postharvest Performance of Potted Ornamental Plants and Plugs}

\author{
Iftikhar Ahmad ${ }^{1,4}$ \\ Department of Horticultural Science, North Carolina State University, 158 \\ Kilgore Hall, 2721 Founders Drive, Raleigh, NC 27695-7609; and the \\ Institute of Horticultural Sciences, University of Agriculture, Faisalabad- \\ 38040, Pakistan \\ Brian E. Whipker ${ }^{2}$ and John M. Dole ${ }^{3}$ \\ Department of Horticultural Science, North Carolina State University, \\ Raleigh, NC 27695-7609
}

Additional index words. Helianthus annuus, Petunia $\times$ hybrida, Tagetes erecta, Zinnia elegans, plant growth retardants, postharvest durability, simulated shipping

\begin{abstract}
Effects of paclobutrazol and ancymidol on postharvest performance and growth control of potted sunflower (Helianthus annuus L.), zinnia (Zinnia elegans Jacq.) and marigold (Tagetes erecta $\mathrm{L}$.), petunia (Petunia $\times$ hybrida Vilm.) plugs, respectively, were studied. Paclobutrazol was applied as a drench at $0,1.0,2.0$, or $4.0 \mathrm{mg}$ of a.i. per $15.2-\mathrm{cm}$ pot for sunflower and $0,0.5,1.0$, or $2.0 \mathrm{mg}$ per $12.5-\mathrm{cm}$ pot for zinnia, while ancymidol was applied at $0,40,80$, and $160 \mathrm{mg} \cdot \mathrm{L}^{-1}$ with a volume of $0.21 \mathrm{~L} \cdot \mathrm{m}^{-2}$ as a foliar spray for marigolds or petunia plug crops. With an increase in paclobutrazol dose or ancymidol concentration, plant growth (plant height and diameter, shoot fresh or dry weight) was controlled for all species tested. Use of $1.0-2.0 \mathrm{mg}$ paclobutrazol per pot produced $21 \%$ to $28 \%$ shorter plants with $12 \%$ to $15 \%$ smaller plant diameter, $13 \%$ to $19 \%$ less shoot fresh weight, $15 \%$ to $21 \%$ less dry weight, and darker green foliage color for potted sunflower than nontreated plants. Treatment with 1.0-4.0 mg paclobutrazol per pot delayed first wilting by 0.7-1.4 days compared with nontreated plants. For zinnia, 0.5-1.0 mg paclobutrazol controlled plant growth, produced dark green foliage, and extended shelf life by delaying first wilting by $2.6-3.9$ days and second wilting by $1.4-2.0$ days than nontreated plants. For marigold and petunia plugs, $40-80 \mathrm{mg} \cdot \mathrm{L}^{-1}$ ancymidol provided ample growth control with darker green foliage; however, postharvest longevity was extended only when plugs were sprayed with $160 \mathrm{mg} \cdot \mathrm{L}^{-1}$ ancymidol. During simulated storage and shipping, plant growth retardants maintained darker green foliage for potted sunflower, zinnia, and marigold plugs and prevented postharvest stem elongation of petunia plugs. In summary, use of plant growth retardants effectively controlled excessive plant growth and extended shelf life of potted plants and plugs.
\end{abstract}

Plant growth regulators (PGRs) are commonly used for ornamental plant production (Whipker, 2013). Among PGRs, triazoles are one of the most popular and effective chemicals for compact ornamental plant production (Arnold, 1998; Jiao et al., 1986; McDaniel, 1990). They have been reported more effective for controlling excessive growth when applied

Received for publication 1 May 2015. Accepted for publication 6 July 2015.

This research was funded by the United States Department of Agriculture Floriculture and Nursery Research Initiative.

We thank Ball FloraPlant for providing cuttings for the study, Fine Americas for donating the PGRs, and Ingram McCall for technical assistance.

Use of trade names in this publication does not imply endorsement by the USDA of products named nor criticism of similar ones not mentioned. ${ }^{1}$ Postdoc Scholar.

${ }^{2}$ Professor.

${ }^{3}$ Professor and Head.

${ }^{4}$ Corresponding author. E-mail: iftikharahmadhashmi@ gmail.com.
(Miranda and Carlson, 1980), application method (Alkhassawneh et al., 2006), formulation/components (Ruter, 1992), and substrate composition (Barrett, 1982). Paclobutrazol was effective in controlling plant size and increasing compactness (Bañón et al., 2001), lowering water use (Hickman, 1986; Ahmad et al., 2014), and decreasing abiotic stresses (Bañón et al., 2006) in ornamental potted and nursery plants. Ancymidol is also used extensively for ornamental plug production and plant growth management (Miranda and Carlson, 1980; Whipker, 2013) or propagation (Maki et al., 2005).

Most PGR studies have focused on controlling plant size and limited work has been reported on secondary effects of PGRs on postharvest durability, plant water or nutrition use, and ethylene sensitivity. A few studies have been reported on the role of paclobutrazol on water stress tolerance in Arachis hypogaea L., C. alismatifolia, and Phillyrea angustifolia L. (Fernandez et al., 2006; Jungklang and Saengnil, 2012; Sankar et al., 2007). However, to our knowledge, no studies have been reported on PGR effect on postharvest durability of bedding plants in pots and plugs.

The specific objectives of this study were to 1) elucidate the effects of two PGRs, paclobutrazol and ancymidol, on postharvest performance of two ornamental potted plants and two plug species and 2) optimize the PGR concentrations for selected floricultural crops. It was hypothesized that use of PGRs would improve postharvest durability by extending shelf life during simulated shipping or marketing.

\section{Materials and Methods}

Research was conducted at the Horticulture Field Laboratory, North Carolina State University, Raleigh, NC, during 2013.

Potted species. Two potted bedding plants, H. annuus 'Pacino Gold' and Z. elegans 'Magellan Pink', were used in the study. Plants were grown in 36-cell trays using Fafard 1P (peatmoss and perlite substrate; Fafard, Anderson, SC) potting substrate. Seedlings were transplanted to either 15.2-cm-diameter (total pot volume of $1275 \mathrm{~mL}$, substrate volume of $1000 \mathrm{~mL}$ ) or 12.5-cm-diameter (total pot volume of $775 \mathrm{~mL}$, substrate volume of $600 \mathrm{~mL}$ ) round plastic pots for sunflower or zinnia, respectively, containing Fafard 1P, at the two-true-leaf stage. For 2 weeks after transplanting, plants were overhead irrigated as needed. Afterward, $48 \mathrm{~h}$ before the PGR applications were done, plants were subirrigated to field capacity (FC) followed by draining for $48 \mathrm{~h}$. The plants were then drenched with $120 \mathrm{~mL}$ solution of paclobutrazol (Piccolo ${ }^{\circledR} 10 \mathrm{XC}$; Fine Americas Inc., Walnut Creek, CA) providing $0,1.0,2.0$, and $4.0 \mathrm{mg}$ a.i. per pot for sunflower, and $60 \mathrm{~mL}$ providing $0,0.5,1.0$, and $2.0 \mathrm{mg}$ a.i. per pot for zinnia. After PGR application, plants were grown to marketing stage, irrigated, and either held at $15^{\circ} \mathrm{C}$ for 2 
or $4 \mathrm{~d}$ or left in the greenhouse under semishade. Afterward, plants were irrigated and placed in the greenhouse under shade to mimic garden center conditions, and their subsequent postharvest durability, as determined by days to wilt, leaf color, and postharvest growth, was recorded. Plants were maintained in a glass greenhouse under natural daylength and light intensity with average $25 / 15{ }^{\circ} \mathrm{C}$ (day/night) temperatures and irrigated every time with water supplied with $250 \mathrm{mg} \cdot \mathrm{L}^{-1}$ nitrogen from a commercial 20-10-20 water-soluble fertilizer intended for soilless substrates (Peters Professional 20-10-20 PLS; Scotts-Sierra Horticultural Products Co., Marysville, $\mathrm{OH}$ ). The experiment was a completely randomized design with eight individual plant replications for both potted plant species comprising a total 96 plants of each species.

Plug species. Two plug crops, T. erecta 'Moonsong Deep Orange' grown from seed and P. ×hybrida 'Suncatcher Coral Prism' grown from vegetative cuttings and rooted under mist, were used in the study. Plugs were grown in 128-cell trays using Fafard $1 \mathrm{P}$ potting substrate. For 1 week after emergence/rooting, plants were irrigated with tap water as needed. Afterward, when plants reached the 2- to 3-new-leaf stage, trays were subirrigated to FC, drained for $30 \mathrm{~min}$, and sprayed uniformly with ancymidol (Abide ${ }^{\circledR}$, Fine Americas Inc.) at 0, 40, 80, and $160 \mathrm{mg} \cdot \mathrm{L}^{-1}$ with a volume of $0.21 \mathrm{~L} \cdot \mathrm{m}^{-2}$. After PGR application, plugs were grown to marketing stage, irrigated every time with water supplied with $250 \mathrm{mg} \cdot \mathrm{L}^{-1}$ nitrogen from a commercial 20-10-20 water-soluble fertilizer intended for soilless substrates, and either held at $15{ }^{\circ} \mathrm{C}$ for 2 or $4 \mathrm{~d}$ or left in greenhouse under semishade. Afterward, plants were irrigated and placed in greenhouse under shade to mimic garden center conditions, and their subsequent postharvest durability, as determined by days to wilt, leaf color, and postharvest growth, was recorded. Growing conditions and management practices were similar as for potted plants. The experiment was a completely randomized design with eight 16 -cell ( $1 / 8$ of the 128 cell) tray sections (one experimental unit was a 16-cell tray) for both plug-grown species comprising a total 96 trays of 16 cells.

Data collection. Data were collected on bud/flower diameter (potted plants only), days to flower (potted plants only), plant height and canopy diameter at the end of production, leaf color at the end of simulated shipping, days to first and second wilt during marketing, and plant height and diameter (potted plants only), shoot fresh weight, dry weight (after drying at $70{ }^{\circ} \mathrm{C}$ for $72 \mathrm{~h}$ ), and leaf color at termination. Plant height was measured from pot rim to top of flower, and plant diameter was measured at two widest dimensions perpendicular to each other and averaged. Days to first wilt were recorded after irrigation and simulated shipping and keeping the plants under semishade in greenhouse. When each plant exhibited wilting signs (visible loss of turgidity, typically on the immature foliage first), days to first wilt were recorded and again irrigated to FC. When each plant showed wilting again, days to second wilt were recorded. Leaf color was measured on a scale of $1-5$, where $1=$ yellow, $2=$ pale green, $3=$ light green, $4=$ green, and $5=$ dark green. The experiment ended when plants wilted for second time during marketing phase.

Statistical analysis. All the data were analyzed using the general linear model procedures of SAS (Version 9.3; SAS Institute, Cary, NC). Means were separated by trend analysis or Fisher's least significance difference, where appropriate, at $P \leq 0.05$.

\section{Results}

Potted sunflower. With increasing PGR dose, plants with shorter height and smaller diameter were produced (Table 1). Moreover, paclobutrazol darkened foliage color and extended postharvest longevity compared with nontreated plants. Results demonstrated the long-term efficacy of paclobutrazol with continued plant growth (plant height, diameter and shoot fresh and dry weight) control during simulated shipping and marketing. Plants with dark green leaves were produced when drenched with $2.0-4.0 \mathrm{mg}$ paclobutrazol. However, plants placed in simulated retail greenhouse environment had slightly darker leaves (4.5) compared with 2 or $4 \mathrm{~d}$ simulated shipping in dark at $15{ }^{\circ} \mathrm{C}$ (4.2 each). Plants kept in simulated shipping for $4 \mathrm{~d}$ had fewer days for second

Table 1. Effect of paclobutrazol on plant height and diameter at the end of production, leaf color at the end of simulated shipping in the dark, days to first wilt during marketing, and plant height and diameter, shoot fresh and dry weight, and leaf color at termination of 'Pacino Gold' potted sunflower. All data represent means with SE of 24 individual potted plants.

\begin{tabular}{|c|c|c|c|c|c|c|c|c|c|}
\hline \multirow[b]{2}{*}{$\begin{array}{l}\text { Paclobutrazol } \\
\text { (mg a.i.) }\end{array}$} & \multirow[b]{2}{*}{$\begin{array}{l}\text { Plant ht } \\
(\mathrm{cm})\end{array}$} & \multirow[b]{2}{*}{$\begin{array}{l}\text { Plant diam } \\
\quad(\mathrm{cm})\end{array}$} & \multirow[b]{2}{*}{$\begin{array}{l}\text { Leaf } \\
\text { color }^{2}\end{array}$} & \multirow[b]{2}{*}{$\begin{array}{l}\text { Days to first } \\
\text { wilt (d) }\end{array}$} & \multicolumn{5}{|c|}{ Termination } \\
\hline & & & & & Plant ht $(\mathrm{cm})$ & $\begin{array}{l}\text { Plant diam } \\
(\mathrm{cm})\end{array}$ & $\begin{array}{c}\text { Shoot fresh } \\
\text { wt (g) }\end{array}$ & $\begin{array}{c}\text { Shoot dry } \\
\text { wt (g) }\end{array}$ & $\begin{array}{l}\text { Leaf } \\
\text { color }^{2}\end{array}$ \\
\hline 0 & $49.1 \pm 0.6$ & $33.6 \pm 0.4$ & $3.6 \pm 0.1$ & $2.5 \pm 0.1$ & $52.3 \pm 0.5$ & $28.2 \pm 0.4$ & $166.1 \pm 3.3$ & $25.7 \pm 1.0$ & $3.6 \pm 0.1$ \\
\hline 1.0 & $38.7 \pm 0.5$ & $29.5 \pm 0.4$ & $4.3 \pm 0.1$ & $3.2 \pm 0.2$ & $42.1 \pm 0.6$ & $26.7 \pm 0.3$ & $144.1 \pm 3.0$ & $21.9 \pm 0.5$ & $4.2 \pm 0.1$ \\
\hline 4.0 & $31.7 \pm 0.6$ & $26.6 \pm 0.4$ & $4.6 \pm 0.1$ & $3.9 \pm 0.1$ & $34.4 \pm 0.6$ & $24.4 \pm 0.4$ & $128.3 \pm 4.6$ & $19.0 \pm 0.8$ & $5.0 \pm 0.0$ \\
\hline \multicolumn{10}{|l|}{ Significance ${ }^{y}$} \\
\hline
\end{tabular}

${ }^{2}$ Rated on a scale of $1-5$, where $1=$ yellow, $2=$ pale green, $3=$ light green, $4=$ green, and $5=$ dark green.

${ }^{y} P$ values were obtained using general linear model procedures of SAS (version 9.3; SAS Institute, Cary, NC) for significant effects of paclobutrazol concentrations.

Ns, Nonsignificant at $P>0.05$.

Table 2. Effect of paclobutrazol on flower diameter, days to flower, plant height and diameter at the end of production, leaf color at the end of simulated shipping in the dark, and days to first or second wilt during marketing phase of 'Magellan Pink' zinnia. All data represent means with SE of 24 individual potted plants.

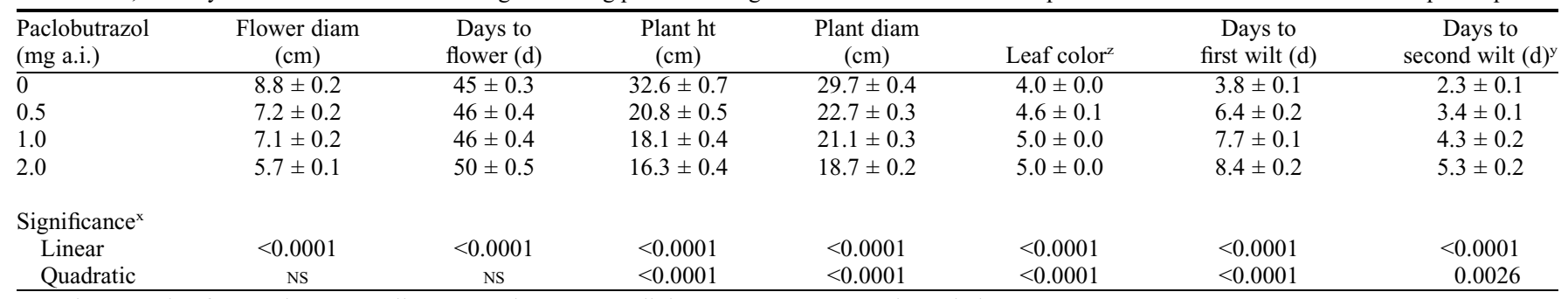

${ }^{\mathrm{z}}$ Rated on a scale of $1-5$, where $1=$ yellow, $2=$ pale green, $3=$ light green, $4=$ green, and $5=$ dark green

${ }^{y}$ Days counted after first wilt.

${ }^{\times} P$ values were obtained using general linear model procedures of SAS version 9.3 for significant effects of paclobutrazol concentrations.

Ns, Nonsignificant at $P>0.05$. 
wilt $(1.8 \mathrm{~d})$ than the plants in greenhouse $(2.7 \mathrm{~d})$ or at $15{ }^{\circ} \mathrm{C}$ for $2 \mathrm{~d}(2.6 \mathrm{~d})$. Use of paclobutrazol delayed flowering by $1-2 \mathrm{~d}$; however, it had no effect on bud diameter (data not presented).

Potted zinnia. Plants drenched with $0.5-1.0 \mathrm{mg}$ paclobutrazol produced $36 \%$ to $44 \%$ shorter plant height, $24 \%$ to $29 \%$ smaller plant diameter, and 1-d delayed flowering
(Table 2). Use of $1.0 \mathrm{mg}$ paclobutrazol produced plants with dark green foliage and delayed first and second wilting by 3.9 and $2.0 \mathrm{~d}$, respectively, during marketing, compared with nontreated plants. Results demonstrated the continued effectiveness of paclobutrazol during simulated shipping and marketing by controlling plant stretch during shipping in dark as witnessed by shorter plant

Table 3. Effect of paclobutrazol on plant height and diameter, fresh and dry weight, and leaf color at termination of 'Magellan Pink' zinnia. All data represent means with SE of 24 individual potted plants.

Paclobutrazol

\begin{tabular}{lccccc}
$(\mathrm{mg}$ a.i. $)$ & Plant ht $(\mathrm{cm})$ & Plant diam $(\mathrm{cm})$ & Shoot fresh wt $(\mathrm{g})$ & Shoot dry wt $(\mathrm{g})$ & Leaf color $^{2}$ \\
\hline 0 & $38.4 \pm 0.9$ & $33.3 \pm 0.4$ & $74.2 \pm 1.6$ & $9.2 \pm 0.2$ & $4.0 \pm 0.0$ \\
0.5 & $23.4 \pm 0.6$ & $23.2 \pm 0.3$ & $50.3 \pm 1.1$ & $5.7 \pm 0.1$ & $5.0 \pm 0.0$ \\
1.0 & $20.3 \pm 0.4$ & $20.2 \pm 0.3$ & $43.8 \pm 1.1$ & $5.0 \pm 0.1$ & $5.0 \pm 0.0$ \\
2.0 & $18.4 \pm 0.4$ & $18.3 \pm 0.2$ & $34.5 \pm 1.0$ & $4.0 \pm 0.1$ & $5.0 \pm 0.0$
\end{tabular}

Significance ${ }^{\mathrm{y}}$

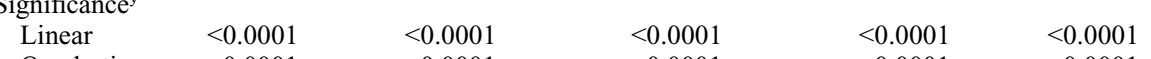

Quadratic

$<0.0001$

$<0.0001$

$<0.0001$ $<0.0001$

${ }^{\mathrm{z}}$ Rated on a scale of $1-5$, where $1=$ yellow, $2=$ pale green, $3=$ light green, $4=$ green, and $5=$ dark green. ${ }^{\mathrm{y}} P$ values were obtained using general linear model procedures of SAS version 9.3 for significant effects of paclobutrazol concentrations.

height, smaller plant diameter, less shoot fresh and dry weight, and dark green leaves at the end of marketing phase (Table 3). Simulated shipping at $15{ }^{\circ} \mathrm{C}$ in dark for $4 \mathrm{~d}$ caused early wilting and minor leaf chlorosis, which were not observed in plants in greenhouse or at $15{ }^{\circ} \mathrm{C}$ in dark for $2 \mathrm{~d}$ (data not presented).

Marigold plugs. Plugs sprayed with $80 \mathrm{mg} \cdot \mathrm{L}^{-1}$ ancymidol had $34 \%$ shorter plant height, 30\% less shoot fresh weight, and $40 \%$ less dry weight at the end of marketing phase (Table 4). Postharvest wilting was delayed by 0.5 and $0.6 \mathrm{~d}$ for first and second wilt, respectively, when plugs were treated with ancymidol at $160 \mathrm{mg} \cdot \mathrm{L}^{-1}$. Simulated shipping at $15^{\circ} \mathrm{C}$ for $4 \mathrm{~d}$ caused minor leaf chlorosis ( 0.3 leaves per plug), produced shorter plant height $(5.3 \mathrm{~cm})$, less shoot fresh weight $(3.9 \mathrm{~g})$, and less dry weight $(0.3 \mathrm{~g})$ than plants simulated in greenhouse (0 leaves per plug, $6.3 \mathrm{~cm}, 5.1 \mathrm{~g}$, and $0.4 \mathrm{~g}$, respectively), which demonstrated effective control of plant stretch during simulated shipping when plugs were sprayed with ancymidol.

Table 4. Effect of ancymidol on plant height at the end of production, days to first or second wilt during marketing, and plant height, and shoot fresh and dry weight at termination of 'Moonsong Deep Orange' marigold plugs. All data represent means with SE of 24 replications of 16-cell plug trays.

\begin{tabular}{|c|c|c|c|c|c|c|}
\hline \multirow{2}{*}{$\begin{array}{l}\text { Ancymidol } \\
\text { concn }\left(\mathrm{mg} \cdot \mathrm{L}^{-1}\right)\end{array}$} & \multirow[b]{2}{*}{ Plant ht $(\mathrm{cm})$} & \multirow[b]{2}{*}{ Days to first wilt (d) } & \multirow[b]{2}{*}{ Days to second wilt $(\mathrm{d})^{\mathrm{z}}$} & \multicolumn{3}{|c|}{ Termination } \\
\hline & & & & Plant ht $(\mathrm{cm})$ & Shoot fresh wt (g) & Shoot dry wt (g) \\
\hline 40 & $3.7 \pm 0.1$ & $2.1 \pm 0.1$ & $2.2 \pm 0.1$ & $5.9 \pm 0.1$ & $4.9 \pm 0.2$ & $0.34 \pm 0.02$ \\
\hline \multicolumn{7}{|l|}{ Significance ${ }^{y}$} \\
\hline Linear & $<0.0001$ & 0.0001 & $<0.0001$ & $<0.0001$ & $<0.0001$ & $<0.0001$ \\
\hline
\end{tabular}

${ }^{\mathrm{z}}$ Days counted after first wilt.

${ }^{\text {y }} P$ values were obtained using general linear model procedures of SAS version 9.3 for significant effects of ancymidol concentrations.

Ns, Nonsignificant at $P>0.05$.

Table 5. Effect of simulated shipping or marketing and ancymidol on leaf color of 'Moonsong Deep Orange' marigold plugs. At the end of the production, plants were subjected to simulated shipping at $15{ }^{\circ} \mathrm{C}$ in the dark for 2 or $4 \mathrm{~d}$ or simulated marketing in greenhouse. All data represent means with sE of eight replications of 16-cell plug trays.

\begin{tabular}{lccc}
\hline Simulated shipping or marketing & Ancymidol concn $\left(\mathrm{mg} \cdot \mathrm{L}^{-1}\right)$ & Leaf color after simulated shipping or storage & Leaf color at termination $^{\mathrm{z}}$ \\
\hline & 0 & $3.0 \pm 0.0 \mathrm{~b}^{\mathrm{y}}$ & $4.0 \pm 0.0 \mathrm{~b}$ \\
& 40 & $4.0 \pm 0.0 \mathrm{a}$ & $4.0 \pm 0.0 \mathrm{~b}$ \\
& 80 & $4.0 \pm 0.0 \mathrm{a}$ & $4.0 \pm 0.0 \mathrm{~b}$ \\
& 160 & $3.1 \pm 0.1 \mathrm{~b}$ & $3.8 \pm 0.2 \mathrm{~b}$ \\
& 0 & $4.0 \pm 0.0 \mathrm{a}$ & $4.0 \pm 0.0 \mathrm{~b}$ \\
& 40 & $4.0 \pm 0.0 \mathrm{a}$ & $4.5 \pm 0.2 \mathrm{a}$ \\
$4 \mathrm{~d}$ at $15^{\circ} \mathrm{C}$ & 80 & $4.0 \pm 0.0 \mathrm{a}$ & $4.8 \pm 0.2 \mathrm{a}$ \\
& 160 & $4.0 \pm 0.0 \mathrm{a}$ & $4.0 \pm 0.0 \mathrm{~b}$ \\
& 0 & $4.0 \pm 0.0 \mathrm{a}$ & $4.0 \pm 0.0 \mathrm{~b}$ \\
Greenhouse & 40 & $4.0 \pm 0.0 \mathrm{a}$ & $4.5 \pm 0.3 \mathrm{a}$ \\
& 80 & $4.0 \pm 0.0 \mathrm{a}$ & \\
Significance & 160 & & \\
Simulation (S) & & $<0.0001$ & $\mathrm{NS}$ \\
Concentration (C) & & $<0.0001$ & $<0.0001$ \\
Linear (L) & & $<0.0001$ & $\mathrm{NS}$ \\
Quadratic (Q) & & $<0.0001$ & 0.0022 \\
S $\times$ CL & & $<0.0001$ & $\mathrm{NS}$
\end{tabular}

${ }^{2}$ Rated on a scale of $1-5$, where $1=$ yellow, $2=$ pale green, $3=$ light green, $4=$ green, and $5=$ dark green.

${ }^{y}$ Mean separation within columns by Fisher's least significant difference at $P \leq 0.05$.

${ }^{\mathrm{x}} P$ values were obtained using general linear model procedures of SAS version 9.3 for significant effects of simulation shipping or marketing and ancymidol concentrations.

Ns, Nonsignificant at $P>0.05$. 
Table 6. Effect of ancymidol on plant height at the end of production, leaf color at the end of simulated shipping in the dark, days to first wilt during marketing, and leaf color and shoot fresh and dry weight at termination of 'Suncatcher Coral Prism' petunia plugs. All data represent means with SE of 24 replications of 16 cell plug trays.

\begin{tabular}{|c|c|c|c|c|c|c|}
\hline \multirow[b]{2}{*}{ Ancymidol concn $\left(\mathrm{mg} \cdot \mathrm{L}^{-1}\right)$} & \multirow[b]{2}{*}{ Plant ht $(\mathrm{cm})$} & \multirow[b]{2}{*}{ Leaf color ${ }^{2}$} & \multirow[b]{2}{*}{ Days to first wilt (d) } & \multicolumn{3}{|c|}{ Termination } \\
\hline & & & & Leaf color ${ }^{z}$ & Shoot fresh wt (g) & Shoot dry wt (g) \\
\hline 0 & $5.3 \pm 0.2$ & $3.0 \pm 0.0$ & $2.4 \pm 0.1$ & $3.2 \pm 0.1$ & $13.0 \pm 0.2$ & $1.06 \pm 0.03$ \\
\hline 40 & $4.4 \pm 0.1$ & $4.0 \pm 0.0$ & $2.6 \pm 0.1$ & $3.7 \pm 0.1$ & $12.5 \pm 0.4$ & $0.99 \pm 0.04$ \\
\hline 80 & $3.8 \pm 0.1$ & $4.0 \pm 0.0$ & $2.7 \pm 0.1$ & $4.0 \pm 0.0$ & $12.0 \pm 0.3$ & $0.94 \pm 0.03$ \\
\hline 160 & $3.3 \pm 0.1$ & $4.0 \pm 0.0$ & $3.0 \pm 0.0$ & $4.0 \pm 0.0$ & $10.1 \pm 0.2$ & $0.76 \pm 0.02$ \\
\hline \multicolumn{7}{|l|}{ Significance $^{\mathrm{y}}$} \\
\hline Linear & $<0.0001$ & $<0.0001$ & $<0.0001$ & $<0.0001$ & $<0.0001$ & $<0.0001$ \\
\hline Quadratic & $<0.0105$ & $<0.0001$ & NS & $<0.0001$ & NS & NS \\
\hline
\end{tabular}

${ }^{\mathrm{z}}$ Rated on a scale of $1-5$, where $1=$ yellow, $2=$ pale green, $3=$ light green, $4=$ green, and $5=$ dark green.

${ }^{y} P$ values were obtained using general linear model procedures of SAS version 9.3 for significant effects of ancymidol concentrations.

Ns, Nonsignificant at $P>0.05$.

Simulated shipping and ancymidol application greatly affected the foliage color (Table 5). Plugs kept continuously in greenhouse conditions had similar leaf color, while those placed in simulated shipping at $15^{\circ} \mathrm{C}$ in dark for 2 or $4 \mathrm{~d}$ and without PGR application had lighter green leaves. However, plugs sprayed with ancymidol at $80-160 \mathrm{mg} \cdot \mathrm{L}^{-1}$ and kept at $15{ }^{\circ} \mathrm{C}$ in dark for $4 \mathrm{~d}$ had darker green leaves compared with those plants with same PGR concentration and kept in greenhouse or stored at $15{ }^{\circ} \mathrm{C}$ for $2 \mathrm{~d}$.

Petunia plugs. Plugs treated with ancymidol produced shorter plants with greener foliage and longer postharvest shelf life (Table 6). Use of ancymidol at $160 \mathrm{mg} \cdot \mathrm{L}^{-1}$ delayed first wilt by $0.6 \mathrm{~d}$ during marketing and produced $22 \%$ less shoot fresh weight and $28 \%$ less dry weight. Simulated shipping at $15{ }^{\circ} \mathrm{C}$ in dark for $4 \mathrm{~d}$ resulted in early wilting $(2.4 \mathrm{~d})$, had higher leaf chlorosis and leaf abscission ( 0.2 or 0.5 leaves per plug, respectively), and less shoot dry weight $(0.93 \mathrm{~g})$ compared with plugs kept in greenhouse $(2.7 \mathrm{~d}$, 0 or 0.3 leaves per plug, and $1.02 \mathrm{~g}$, respectively).

Use of ancymidol continued to control plant stretch during simulated shipping in dark, as plugs sprayed with ancymidol at $160 \mathrm{mg} \cdot \mathrm{L}^{-1}$ and placed at $15^{\circ} \mathrm{C}$ in dark for $4 \mathrm{~d}$ had similar change in plant height at the end of marketing as the plugs kept in greenhouse (Table 7).

\section{Discussion}

Production of small, compact plants may offer an economic benefit to commercial greenhouse producers as small-sized plants can be placed closer to each other and result in greater space utilization efficiency. As PGR concentration increased, plant growth (fresh weight, dry weight, plant height, and diameter) was smaller and postharvest longevity was extended for all tested species. For potted sunflower, the optimal concentration of paclobutrazol for longest postharvest shelf life was $2.0 \mathrm{mg}$ a.i., which had $40 \%$ longer shelf life and delayed wilting than nontreated plants (Table 1). Dasoju et al. (1998) similarly noted that paclobutrazol was effective on controlling sunflower plant growth and recommended 2-4 $\mathrm{mg}$ a.i. per pot, with up to $8 \mathrm{mg}$ in the summer. For potted zinnia,

Table 7. Effect of simulated shipping or marketing and ancymidol on termination plant height and change in plant height of 'Suncatcher Coral Prism' petunia plugs. At the end of the production, plants were subjected to simulated shipping at $15^{\circ} \mathrm{C}$ in the dark for 2 or $4 \mathrm{~d}$ or simulated marketing in greenhouse. All data represent means with SE of eight replications of 16-cell plug trays.

\begin{tabular}{lccc}
\hline $\begin{array}{l}\text { Simulated shipping } \\
\text { or marketing }\end{array}$ & $\begin{array}{c}\text { Ancymidol } \\
\text { concn }\left(\mathrm{mg} \cdot \mathrm{L}^{-1}\right)\end{array}$ & $\begin{array}{c}\text { Termination } \\
\text { plant ht }(\mathrm{cm})\end{array}$ & $\begin{array}{c}\text { Change in } \\
\text { plant ht }(\mathrm{cm})\end{array}$ \\
\hline & 0 & $8.5 \pm 0.3 \mathrm{~b}^{\mathrm{z}}$ & $3.1 \pm 0.1 \mathrm{bc}$ \\
& 40 & $6.7 \pm 0.2 \mathrm{~d}$ & $2.7 \pm 0.2 \mathrm{~cd}$ \\
$2 \mathrm{~d}$ at $15{ }^{\circ} \mathrm{C}$ & 80 & $5.8 \pm 0.2 \mathrm{e}$ & $2.4 \pm 0.1 \mathrm{de}$ \\
& 160 & $5.0 \pm 0.4 \mathrm{e}$ & $3.9 \pm 0.3 \mathrm{ef}$ \\
& 0 & $9.4 \pm 0.4 \mathrm{a}$ & $3.5 \pm 0.3 \mathrm{ab}$ \\
$4 \mathrm{~d}$ at $15{ }^{\circ} \mathrm{C}$ & 40 & $8.0 \pm 0.4 \mathrm{bc}$ & $3.2 \pm 0.2 \mathrm{bc}$ \\
& 80 & $7.2 \pm 0.4 \mathrm{~cd}$ & $1.7 \pm 0.1 \mathrm{f}$ \\
& 160 & $5.1 \pm 0.2 \mathrm{e}$ & $3.4 \pm 0.1 \mathrm{ab}$ \\
Greenhouse & 0 & $8.4 \pm 0.3 \mathrm{~b}$ & $3.3 \pm 0.1 \mathrm{bc}$ \\
& 80 & $7.9 \pm 0.3 \mathrm{bc}$ & $3.1 \pm 0.2 \mathrm{bc}$ \\
& 160 & $7.3 \pm 0.2 \mathrm{~cd}$ & $1.9 \pm 0.2 \mathrm{ef}$
\end{tabular}

Significance ${ }^{\mathrm{y}}$

Simulation (S)

0.0004

0.0008

Concentration (C)

Linear (L)

Quadratic (Q)

$<0.0001$

$<0.0001$

0.0105

$<0.0001$

$<0.0001$

$\mathrm{S} \times \mathrm{CL}$

$\mathrm{S} \times \mathrm{CQ}$

NS

0.0228

${ }^{\mathrm{z}}$ Mean separation within columns by Fisher's least significant difference at $P \leq 0.05$.

${ }^{y} P$ values were obtained using general linear model procedures of SAS version 9.3 for significant effects of simulated shipping or marketing and ancymidol concentrations.

Ns, Nonsignificant at $P>0.05$.

optimal concentration would be $0.5-1.0 \mathrm{mg}$ paclobutrazol as it extended shelf life and delayed wilting by $68 \%$ to $80 \%$ the first time and by $48 \%$ to $87 \%$ the second time during marketing compared with nontreated plants (Table 2). Use of paclobutrazol continued to control plant stretch during simulated shipping, which was evident from smaller plant height and diameter and less shoot fresh and dry weight of plants (Tables 1 and 3). Similar findings have also been reported by Cox and Keever (1988), Ecker et al. (1992), and Keever and Cox (1989), who reported less biomass and growth control of marigold, stock, and zinnia plants treated with paclobutrazol. Suppression of plant growth may be due to less internodal elongation as reported by Arnold (1998) in verbena (Verbena canadensis L.) and lantana (Lantana horrida H.B.K.) and by Pinto et al. (2005) in zinnia. Moreover, paclobutrazol-drenched plants produced leaves with dark green color, which might be due to effect of paclobutrazol on enhancement of chlorophyll biosynthesis and reduction of leaf expansion (Davis et al., 1988; Halmann, 1990). PGRs also have several secondary affects when the GA biosynthesis pathway is suppressed such as less leaf area and lower water usage (Rademacher, 2000). Gradual increase in paclobutrazol dose subsequently controlled excessive plant growth of both potted species as reported in several other studies, such as carnation (Dianthus caryophyllus L.) (Bañón et al., 2002) and ornamental pepper (Capsicum annuum L.) (Starman, 1993).

No phytotoxicity symptoms were observed in tested potted plants when drenched with higher paclobutrazol doses. Increasing paclobutrazol dose effectively delayed postharvest wilting and extended potential shelf life, which was probably due to compact plant growth with less transpirational surface area and number of stomata, increased leaf thickness or stomatal density, or induction of water stress tolerance (Burrows et al., 1992; Sankar et al., 2007; Sankhla et al., 1985). 
For plug species, foliar application of 80-160 $\mathrm{mg} \cdot \mathrm{L}^{-1}$ ancymidol provided ample plant growth control, delayed postharvest wilting, and extended shelf life by $15 \%$ to $30 \%$ for marigold and $12 \%$ to $25 \%$ for petunia (Tables 4 and 6). Moreover, plugs sprayed with $80 \mathrm{mg} \cdot \mathrm{L}^{-1}$ ancymidol and subjected to simulated shipping for $4 \mathrm{~d}$ had dark green foliage compared with the plugs of similar concentration-treated plants simulated in greenhouse (Table 5). PGR effectively controlled plant stretch during shipping, and plugs treated with $160 \mathrm{mg} \cdot \mathrm{L}^{-1}$ ancymidol followed by simulated shipping at $15{ }^{\circ} \mathrm{C}$ for $4 \mathrm{~d}$ had similar change in plant height at termination as plants held in the greenhouse (Table 7). Davis (1991) noted that PGRs were effective in controlling growth of zinnia and marigold plugs for up to 4 weeks after transplanting to the final container, depending on the concentration used during production. Our results demonstrated effectiveness of the PGR application for lowering shipment cost by increasing shipping capacity, maintaining plant size and quality during simulated shipment, and improving tolerance to shipping and handling stresses (Latimer and Whipker, 2012). No phytotoxicity symptoms were observed in petunia; however, moderate PGR damage on leaf tips and margins of marigold plugs were observed with highest concentration. Damage was less on new foliage compared with older leaves. Phytotoxicity of higher PGR doses have also been reported on carnation (Foley and Keever, 1991) and lavender (Papageorgiou et al., 2002). For these species, plants sprayed with $80 \mathrm{mg} \cdot \mathrm{L}^{-1}$ had better visual appearance and more compact growth, while $160 \mathrm{mg} \cdot \mathrm{L}^{-1}$ was optimal for extension of postharvest shelf life compared with nontreated plants.

Both paclobutrazol and ancymidol have been used in commercial greenhouses for over 20 years. Their labels contain worker protection standard recommendations for their use, which are not very extensive, and the reentry period is only $12 \mathrm{~h}$. Therefore, they are considered beneficial and hazard free, if used following precautionary measures printed on their labels.

\section{Conclusions}

Application of paclobutrazol or ancymidol not only controlled excessive plant growth, but also delayed wilting and extended the postharvest longevity of all tested species plus kept potted plants and plugs in a marketable condition for a longer period. Producers should consider extending shelf life of ornamental plants by using tested PGRs in addition to the traditional benefit of growth control as a best management practice to increase financial returns per unit cost.

\section{Literature Cited}

Ahmad, I., B.E. Whipker, J.M. Dole, and I. McCall. 2014. Paclobutrazol and ancymidol lower water use of potted ornamental plants and plugs. European J. Hort. Sci. 79:318-326.

Alkhassawneh, N.M., N.S. Karam, and R.A. Shibli. 2006. Growth and flowering of black iris (Iris nigricans Dinsm.) following treatment with plant growth regulators. Sci. Hort. 107:187-193. Arnold, M.A. 1998. Size control and postproduction growth of container grown perennial verbena, cherry sage, and lantana drenched with paclobutrazol. Plant Growth Regul. Soc. Amer. Quart. 26:144-156.

Banko, T.J. and M.A. Stefani. 1988. Growth response of selected container-grown bedding plants to paclobutrazol, uniconazole, and daminozide. J. Environ. Hort. 6:124-129.

Bañón, S., A. González, E.A. Cano, J.A. Franco, and J.A. Fernández. 2002. Growth, development and color response of potted Dianthus caryophyllus cv. Mondriaan to paclobutrazol treatment. Sci. Hort. 94:371-377.

Bañón, S., J. Ochoa, and A. González. 2001. Manipulation of oleander growth, development and foliage color by paclobutrazol and ethephon. Gartenbauwissenschaft 66:123-132.

Bañón, S., J. Ochoa, J.A. Franco, J.J. Alarcón, and M.J. Sánchezblanco. 2006. Hardening of oleander seedlings by deficit irrigation and low air humidity. Environ. Exp. Bot. 56:36-44.

Barrett, J.E. 1982. Chrysanthemum height control by ancymidol, PP333 and EL-500 dependent upon medium composition. HortScience 17:896-897.

Burrows, G.E., T.S. Boag, and W.P. Stewart. 1992. Changes in leaf, stem, and root anatomy of Chrysanthemum cv. Lillian Hoek following paclobutrazol application. J. Plant Growth Regul. 11:189-194.

Chen, C.L., G.L. Keever, and C.F. Deneke. 1993 Growth and flowering of triazole-treated zinnia (Zinnia elegans) and marigold (Tagetes erecta). Plant Growth Reg. Soc. Amer. Quar. 21:169-179.

Cox, D.A. and G.J. Keever. 1988. Paclobutrazol inhibits growth of zinnia and geranium. HortScience 23:1029-1030.

Cramer, C.S. and M.P. Bridgen. 1998. Growth regulator effects on plant height of potted Mussaenda 'Queen Sirikit'. HortScience 33:78-81.

Dasoju, S., M.R. Evans, and B.E. Whipker. 1998. Paclobutrazol drenches control growth of potted sunflowers. HortTechnology 8:235-237.

Davis, T. 1991. Post-production performance of uniconazole-treated zinnia and marigold plugs. HortTechnology 1:49-52.

Davis, T.D., G.L. Stefens, and N. Sankhla. 1988 Triazole plant growth regulators. Hort. Rev. 10:63-105.

Ecker, R., A. Barzilay, L. Afgin, and A.A. Watad. 1992. Growth and flowering responses of Matthiola incana L.R. BR. to paclobutrazol. HortScience 27:1330.

Fernandez, J.A., L. Balenzategui, S. Banon, and J.A. Franco. 2006. Induction of drought tolerance by paclobutrazol and irrigation deficit in Phillyrea angustifolia during the nursery period. Sci. Hort. 107:277-283.

Foley, J.T. and G.J. Keever. 1991. Growth regulators and pruning alter growth and axillary shoot development of Dianthus. J. Environ. Hort. 9:191-195.

Gilbertz, D.A. 1992. Chrysanthemum response to timing of paclobutrazol and uniconazole sprays. HortScience 27:322-323.

Halmann, M. 1990. Synthetic plant growth regulators. Adv. Agron. 43:47-105.

Hickman, G.W. 1986. A new growth regulator for greenhouse plants. Calif. Agr. 16-17.

Jiao, J., M.J. Tsujita, and D.P. Murr. 1986. Effects of paclobutrazol and A-Rest on growth, flowering, leaf carbohydrate and leaf senescence in 'Nellie White' Easter lily (Lilium longiflorum Thunb.). Sci. Hort. 30:135-141.
Jungklang, J. and K. Saengnil. 2012. Effect of paclobutrazol on patumma cv. Chiang Mai Pink under water stress. Songklanakarin J. Sci. Technol. 34:361-366.

Keever, G.J. and D.A. Cox. 1989. Growth inhibition in marigold following drench and foliar applied paclobutrazol. HortScience 24:390.

Kim, H.Y., H. Watanabe, and Y. Suzuki. 1992. Effect of growth retardant uniconazole on the floral formation of Zinnia elegans Jacq. J. Jpn. Soc. Hortic. Sci. 61:603-608.

Latimer, J.G. and B.E. Whipker. 2012. Selecting and using plant growth regulators on floricultural crops. Virginia Coop. Ext. Pub. Hort. p. 43.

Maki, S.L., M. Delgado, and J.W. Adelberg. 2005. Time course study of ancymidol for micropropagation of Hosta in a liquid culture system. HortScience 40:764-766.

McDaniel, G.L. 1986. Comparison of paclobutrazol, flurprimidol, and tetcyclacis for controlling poinsettia height. HortScience 21:1161-1163.

McDaniel, G.L. 1990. Postharvest height suppression of potted tulips with paclobutrazol. HortScience 25:212-214.

Miranda, R.M. and W.H. Carlson. 1980. Effect of timing and number of applications of chlormequat and ancymidol on the growth and flowering of seed geraniums. J. Amer. Soc. Hort. Sci. 105:273-277.

Papageorgiou, I., P. Giaglaras, and E. Maloupa. 2002. Effects of paclobutrazol and chlormequat on growth and flowering of lavender. HortTechnology 12:236-238.

Pinto, A.C.R., T.J.D. Rodrigues, I.C. Leite, and J.C. Barbosa. 2005. Growth retardants on development and ornamental quality of potted 'Lilliput' Zinnia elegans Jacq. Sci. Agr. 62:337-345.

Pinto, A.C.R., T.T. Graziano, J.C. Barbosa, and F.B. Lasmar. 2006. Growth retardants on production of flowering potted Thai tulip. Bragantia 65:369-380.

Rademacher, W. 2000. Growth retardants: Effects on gibberellin biosynthesis and other metabolic pathways. Annu. Rev. Plant Physiol. Mol. Biol. 51:501-531.

Ruter, J.M. 1992. Growth and flowering response of butterfly-bush to paclobutrazol formulation and rate of application. HortScience 27:929.

Sankar, B., A. Jaleel, P. Manivannan, A. Kishorekumar, R. Somasundaram, and R. Panneerselvam. 2007. Effect of paclobutrazol on water stress amelioration through antioxidants and free radical scavenging enzymes in Arachis hypogaea L. Colloids Surf. B Biointerfaces 60:229-235.

Sankhla, N., T.D. Davis, A. Upadhyaya, D. Sankhla, R.H. Walser, and B.N. Smith. 1985. Growth and metabolism of soybean as affected by paclobutrazol. Plant Cell Physiol. 26:913-921.

Singh, N.P., C.S. Malhi, and W.S. Dhillion. 2004 Effect of plant bioregulators on the promotion of flowering in mango cv. Dusehri. J. Res. Punjab Agr. Univ. 3:341-344.

Starman, T.W. 1993. Ornamental pepper growth and fruiting response to uniconazole depends on application time. HortScience 28:917-919.

Whipker, B.E. 2013. Plant growth regulator guide. GrowerTalks. p. 1-37.

Whipker, B.E. and S. Dasoju. 1998. Potted sunflower growth and flowering responses to foliar applications of daminozide, paclobutrazol, and uniconazole. HortTechnology 8:86-88.

Whipker, B.E. and I. McCall. 2000. Response of potted sunflower cultivars to daminozide foliar sprays and paclobutrazol drenches. HortTechnology 10:209-211. 